IJSHE

9,2

170

Received 27 December 2006

Revised 2 May 2007

Accepted 28 August 2007

\section{Sustainability and ethics as decision-making paradigms in engineering curricula}

\author{
Abbas El-Zein and David Airey \\ School of Civil Engineering, University of Sydney, Sydney, Australia \\ Peter Bowden \\ Department of Philosophy, University of Sydney, Sydney, Australia, and \\ Henriikka Clarkeburn \\ Department of Economics, University of Sydney, Sydney, Australia
}

\begin{abstract}
Purpose - The aim of this paper is to explore the rationale for teaching sustainability and engineering ethics within a decision-making paradigm, and critically appraise ways of achieving related learning outcomes.

Design/methodology/approach - The paper presents the experience of the School of Civil Engineering at the University of Sydney in teaching environmental sustainability and engineering ethics to third-year undergraduate students. It discusses the objectives of the course and the merits and drawbacks of incorporating ethics and sustainability in the same teaching framework. In addition, it evaluates ways of incorporating theoretical and applied perspectives on sustainability.

Findings - Ethics and sustainability overlap but do not coincide; incorporating them in the same engineering course can be effective, provided that points of linkage are clearly recognized in the syllabus, a suitable combination of theory and practical applications is drawn upon and adequate teaching methods, including decision-making case problems, are used.

Research limitations/implications - While environmental sustainability, economic rationality and ethical reasoning can be easily fitted into the syllabus, social sustainability is more difficult to teach because it requires a significant conceptual departure from deep-seated preconceptions on the part of students and teachers, and does not lend itself easily to conventional classroom activity, such as lectures and weekly workshops. Further research on effective ways of incorporating social sustainability in engineering curricula is therefore needed.
\end{abstract}

Originality/value - The paper evaluates sustainability issues within the context of civil engineering education.

Keywords Civil engineering, Ethics, Sustainable development, Decision making

Paper type Case study

\section{Introduction}

Engineering graduates apply their technical skills in a wide variety of legal, institutional, and environmental settings, acting as agents of technology-driven social change. While problem solving has been a much-lauded hallmark of engineering education and practice, decision making is an equally necessary, if less publicized, skill that engineers are expected to possess. Decision making is made all the more complex by a number of technical, economic, environmental, social and ethical constraints. In particular, environmental sustainability has given rise to a new framework of

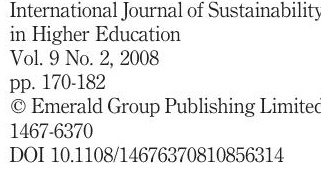


engineering analysis that is now an essential part of the work of engineers. For example, the triple bottom line approach to reporting systematically incorporates environmental sustainability, social impacts, labour considerations and economic costs in engineering decision making (GRI, 2006). Social sustainability considerations, on the other hand, have been slower to emerge in engineering teaching, not least because of the difficulty of defining the concept (Daly, 1992). Nevertheless, a number of issues recur in engineering practice and syllabi under the umbrella of social sustainability, such as the impacts of engineering projects on rural and urban communities, the redistributive effects of infrastructure development, participatory decision making in urban planning and land management, and the role of engineers as stakeholders with specific interests in these processes.

Engineering curricula, like those of many applied sciences, typically start with foundation courses in mathematics, physics and chemistry, before moving to applied engineering subjects which focus on the analysis of technical problems and the design of engineering solutions for them. Little teaching time has traditionally been allocated to the wider social, political and environmental settings of engineering practice. The engineering community has been aware of the limitations of an exclusively technological focus for some time (Johnston et al., 2000). Over the last decade or so, many engineering departments around the world have modified their curricula to cater for the increasing importance of environmental and social concerns in the wider community (Turner et al., 2001; Paten et al., 2005; Geli de Ciurana, 2006).

Questions therefore arise about the best way to teach environmental sustainability, ethical decision making and social responsibility. No single framework or template appears to have emerged from the literature. Some departments have introduced new environmental components in their degrees (Nair, 1998; Dick and Stimpson, 1999; Wiedenhoeft, 1999) while others have focused on the developmental aspect of engineering in poorer countries (Pérez-Foguet et al., 2005). More ambitiously, a few engineering schools and faculties have attempted to introduce engineering-related environmental and social issues from within existing technical courses in analysis and design (Turner et al., 2001; Abdul-Wahab et al., 2003; Paten et al., 2005; Fenner et al., 2005). However, a number of authors have drawn attention to the difficulties of introducing such large-scale, multi-actor change to the curriculum (Bryce et al., 2004; Peet et al., 2004). Boyle (2004) points out a number of specific obstacles in teaching sustainability to engineering students such as lack of time in the degree, lack of student maturity and lack of available examples. Vanderburg (1999) suggests an educational framework which aligns sustainability with preventative, as opposed to remedial, engineering and assesses the extent to which the impacts of technology is taught at US engineering colleges. However, the author says little about the best way to conduct such teaching. Dick and Stimpson (1999) describe a course in technology and society which emphasizes an analytical understanding of the impacts of technology, past, present and future. While the course has been effective in drawing students into these debates, it does not provide for a systematic approach to decision making that might emerge from these insights. Gondran et al. (2003) and Lourdel et al. (2005) describe a method of teaching multi-stakeholders dynamics in environmental decision making based on specially designed games that students play. However, there is little in the literature about teaching social sustainability to engineering students. 
IJSHE 9,2

Teaching ethics in engineering raises equally complex questions. Authors on the subject appear to agree that case problems which foreground the ethical dimensions of technical decisions are essential tools in teaching ethics (Gorman et al., 2000). Reporting the results of a Rest's Defining Issues Test, Self and Ellison (1998) have found significant improvements in the moral reasoning skills of students after they sat an engineering ethics course. However, Drake et al. (2005) shows that, at least in one particular case, two different approaches - a dedicated course and a module within a wider course - yielded little change in moral reasoning capacity. More fundamentally, in a meta-analysis of papers on teaching ethics to engineering students in the USA, Haws (2001) finds that, although a number of approaches for teaching ethics are used, very little reference to ethical theory is made in their syllabi. Issues specific to teaching ethics and sustainability in the same module appear to have been discussed in only one paper. Nair (1998) reports a curricular experience in which life-cycle analysis, design and environmental conservation lead to ethical questions. However, in this case, the course appears to remain technically focused and little by way of social sustainability and large-scale infrastructure decision making is covered.

It is clear from the above review that many questions concerning the theoretical and practical content of both ethics and sustainability courses, as well as their overall objectives, remain. A new course has been recently introduced at the School of Civil Engineering of the University of Sydney, whose main aim is to expose students to issues of environmental and social sustainability as well as ethics in civil engineering practice. In this paper, we will draw on our experience in designing and delivering this course to discuss the following questions:

(1) How can environmental and social sustainability and professional ethics be taught as part of the same decision-making paradigm?

(2) What conceptual and practical difficulties and limitations may be encountered?

The paper is divided into three parts. The objectives and the structure of the course are first described and the course layout presented. Next, the questions raised above are discussed and answers are offered. Finally, conclusions are drawn and recommendations for future research are made.

\section{Context}

The Civil Engineering program at the University of Sydney was re-organized in 2003 and a new third-year unit of study entitled "Engineering and Society" was added to the core program (Airey et al., 2005). The main objectives of the course were to:

- introduce students to important ecological, social and ethical issues including new paradigms of environmental sustainability, and the way they affect engineering decision making;

- develop students' skills in sustainable design;

- improve the capacity of students at identifying the impacts of engineering projects on the social and natural environments, and developing alternative solutions to problems; and

- develop students decision-making skills under environmental, social and ethical constraints. 
The course also aimed to improve the communication skills of students in verbal and written media, as well as their team-work ability. These skills were deemed crucial to the task of appraising the wider environmental, social and ethical implications of engineering projects and developing answers to them in a multi-stakeholder environment.

The course layout is shown in Figure 1. It begins with a set of lectures and group workshops on environmental engineering topics, with particular emphasis on the way civil engineering projects impact physical and social ecosystems. Examples are drawn from mining, hydraulic and urban planning issues such as housing and transport. Some numerical skills, such as the interpretation of air pollution records and standards, and the estimation of greenhouse gas emissions, are taught. The workshops require students to read specific decision-making scenarios, perform some data calculations then engage with policy issues, identifying and analyzing stakeholder positions and making specific recommendations. Building on this material, students are then introduced to concepts of sustainability, in its "weak" and "strong" forms, substitutability of natural and man-made capital, as well debates surrounding its definitions and practical applications in engineering (Neumayer, 2004). Next, the concept is put into practice through lectures on sustainable design, including practical exercises related to the building development process. Approaching design as a decision-making exercise encourages students to go

\section{LECTURE TOPICS}

Timeline

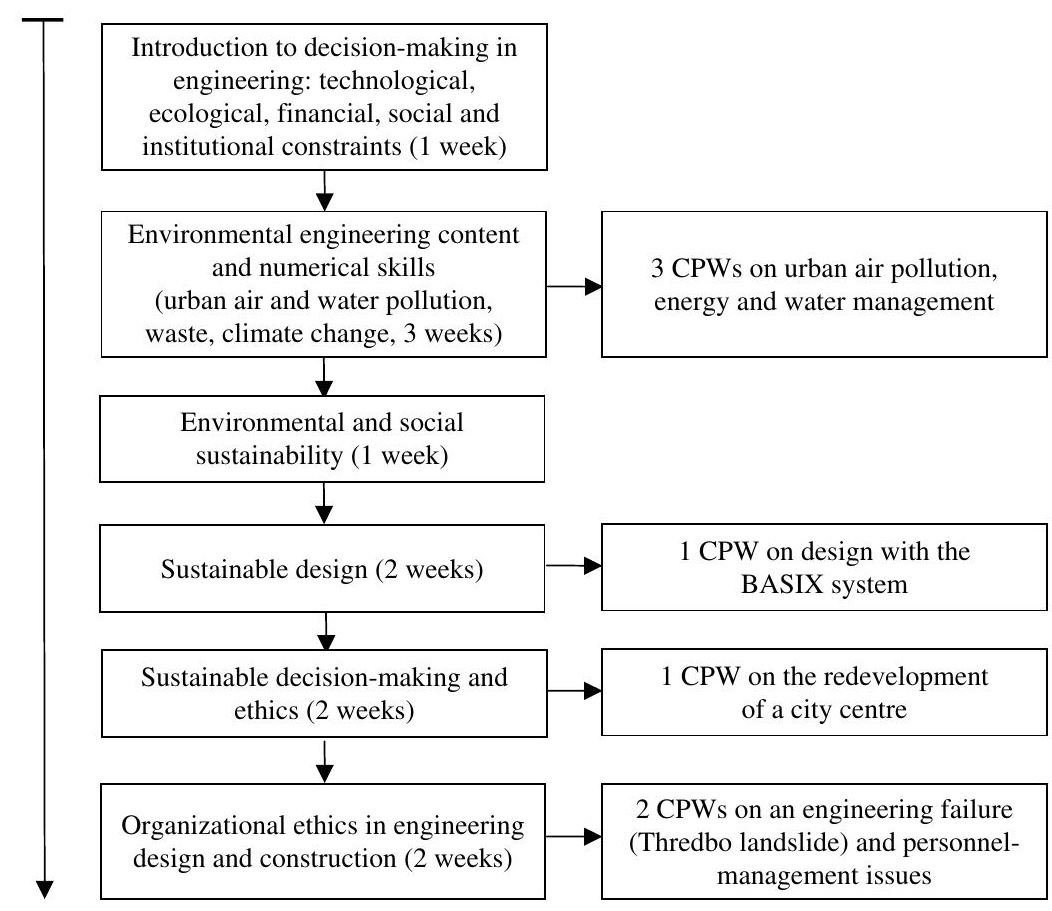

Decision-making paradigms

173
Figure 1. Course layout 


\section{IJSHE 9,2}

Table I.

Learning objectives matrix on a scale of 1 (weak contribution to objective) to 4 (strong contribution to objective) beyond the development of technical solutions to incorporate impact assessment and stakeholder conflicting interests in their practice. Finally, the students are deemed ready to tackle more complex, and less technical, questions of multi-stakeholder decisions of sustainability and ethics, in a more systematic way, at various scales, from interpersonal relationships in organizations to infrastructure planning at metropolitan and national levels. Lectures and group workshops on decision-making processes are delivered.

All in all, three teaching-and-learning methods are used: weekly lectures, weekly case-problem workshops and semester-long projects. Table I shows the learning objectives matrix of the course. Both the workshops and the projects require students to work in groups of 4 or 5. The group-work teams are formed by the course coordinator for the workshops, while the project teams are assembled by the students themselves with help from instructors if needed. The students are hence exposed to two kinds of team-work which are likely to generate different interaction dynamics. Typically, 120-140 students enroll in the course and the decision-making workshops provides an opportunity for interaction among students, and between students and staff. Each workshop runs as follows. Students read the decision-making scenarios individually and perform some data analysis before coming to the workshop. On the day of the workshop, the class is divided into four sections with six or seven groups meeting in a classroom and each group sitting around a table for the first two hours of the workshop, discussing policy issues in order to reach decisions about specific issues. Then, a plenary session for the section is conducted. One lecturer and one tutor are at hand to assist in group discussions and run the plenary session. Finally, the projects

\begin{tabular}{|c|c|c|c|c|}
\hline Category & Objectives & Lectures & $\mathrm{CPW}^{\mathrm{a}}$ & Projects \\
\hline \multirow[t]{5}{*}{ Primary } & $\begin{array}{l}\text { Introduce students to important ecological, social } \\
\text { and ethical issues deriving from technology-driven } \\
\text { change, including new paradigms of environmental } \\
\text { sustainability, and the way they affect engineering } \\
\text { decision-making }\end{array}$ & 4 & 4 & 4 \\
\hline & $\begin{array}{l}\text { To develop students' skills at sustainable design and } \\
\text { the use of design tools relevant to the development } \\
\text { process in New South Wales, Australia }\end{array}$ & 3 & 4 & $\mathrm{~V}^{\mathrm{b}}$ \\
\hline & $\begin{array}{l}\text { To improve the capacity of students at identifying } \\
\text { the impacts of engineering projects on the social and } \\
\text { natural environments, and developing alternative } \\
\text { solutions to problems }\end{array}$ & 2 & 3 & 4 \\
\hline & $\begin{array}{l}\text { To develop students decision-making skills under } \\
\text { environmental and ethical constraints }\end{array}$ & 1 & 3 & $\mathrm{~V}^{\mathrm{b}}$ \\
\hline & $\begin{array}{l}\text { To develop the students' understanding of the } \\
\text { influence of organizational, ethical and legal factors } \\
\text { on engineering practice }\end{array}$ & 4 & 3 & 2 \\
\hline \multirow[t]{3}{*}{ Secondary } & $\begin{array}{l}\text { To improve the communication skills of students, } \\
\text { through verbal and written media }\end{array}$ & & 4 & 4 \\
\hline & To improve the team-work ability of students & & 4 & 4 \\
\hline & $\begin{array}{l}\text { To improve students skills in research and use of } \\
\text { library resources }\end{array}$ & & 3 & 4 \\
\hline
\end{tabular}

Notes: ${ }^{a} \mathrm{CPW}$ is case-problem workshop; "variable": used in relation to the contribution of the projects to some objectives, which depends on the particular project topic of each particular group 
give students the opportunity to work on a single topic for the whole semester, Decision-making allowing for in-depth analysis than the workshop.

paradigms

\section{Discussion}

Rationale for course structure

The course clearly carries three components:

(1) environmental and social impacts of engineering;

(2) ethical decision making in engineering; and

(3) communication and research skills of engineers.

The rationale for grouping these components in one course is based on the ethical dimension of environmental and social sustainability, and the multi-stakeholder nature of the decision-making processes in this field. The latter requires engineers to develop the ability to communicate with partners from a wide range of disciplinary and social backgrounds. However, the connection between the three components does not, in itself, tell us how the course should be structured. For example, while many environmental sustainability issues carry a strong ethical dimension, some issues in engineering practice (such as bidding processes, personnel management and construction safety) are essentially ethical problems with no obvious environmental sustainability dimension. Devon (1999) argues for a new engineering social ethics which "takes as problematic the mutable social arrangements for decision making in technology" as opposed to an ethics of "company loyalty, technocratic leadership and social responsibility". This perspective has been useful to us in consolidating the course framework and providing coherent links between its constituent parts. In his discussion of the teaching of ethics to engineers, Haws (2001) places high value on John Rawls conception of inequality, "only justifiable to the extent that it does improve the access to primary goods of the least advantaged". This perspective articulates in effect a powerful connection between ethics and social equity in so far as it justifies the social power and financial privilege of engineers through its potential for serving the "least advantaged". Such connections are doubly effective. First, they provide a strong thread running through the course and linking sustainability to ethics. Second, they promote "deep" learning by encouraging students in the workshops to engage with the course material as decision-makers, rather than observers or passive learners.

Another issue in the course design is how to make the course attractive to students who usually view technical subjects as the only essential part of their curricula. The perceived "qualitative" nature of the course is bound to devalue it in the eyes of applied science students who often equate "usefulness" with numerically-based design and analysis skills, rather than conceptual re-thinking, communications across disciplinary boundaries and complex decision-making where technical knowledge is only one among several other considerations. This obstacle is particularly significant when the relationship of the course learning outcomes to professional practice are articulated in the classroom (Table II). While the relevance of the learning outcomes is not in doubt, many students see "technical design and execution" as the only skill worthy of their curricular time. The problem, in other words, is not only how to change deep-seated mental habits and get students to think outside the "technical" box. It is also one in which students are asked to rethink what is significant in their curriculum and future careers. On the second and third delivery of the course, we have introduced two 


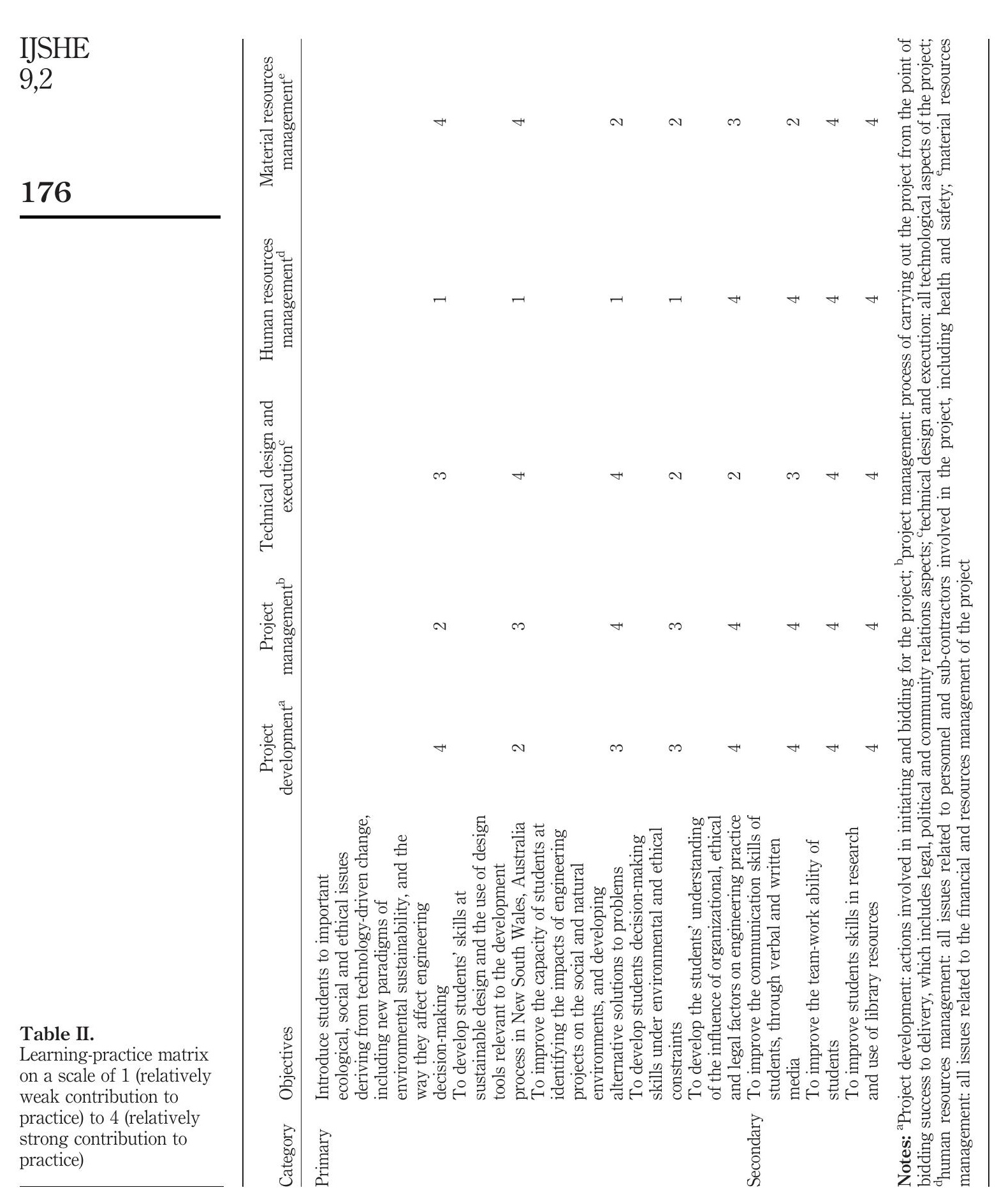


changes to deal with this issue. First, we have engaged students in a discussion about their perception of their future professional paths, using scenarios shown in Table III, and have introduced the course learning outcomes through this discussion. Second, we have re-arranged the course structure and, rather than tackling sustainability concepts head on, gradually raised sustainability issues by building on environmental engineering technical material such as energy and climate change, land use and habitat loss. Starting with environmental engineering content fulfills three functions. First, it allows students to begin engaging with the course on a relatively familiar note with technical material, including numerical skills. Second, it provides building-blocks which will then lead to policy and decision-making questions of sustainability and ethics. Third, it introduces ethics as a more systematic way of thinking about some decisions in engineering which include, but are not limited to, sustainability. Hence, all theoretical and policy questions and discussions are strongly rooted in engineering perspectives.

Students have responded positively to this approach but engaging them in the learning process proved to be difficult at times. The case problems we used proved to be somewhat deficient in sustaining the self and peer-learnings processes of group work. In addition, a number of students have expressed the need for more time spent on articulating the practical implications of social and environmental sustainability. The above two issues are discussed next.

\section{Case problems}

Identifying and designing suitable case problems for workshops has been a major obstacle in course delivery. In a survey of current teaching practices in the USA, Heckert (2000) reports that case-problem teaching is more commonly used in teaching engineering ethics than methods based on codes of ethics or moral theory. A wide variety of engineering ethics and sustainability case studies do exist in the literature and many are available online (Wilcox, 1998; www.onlineethics.org). However, very few are case problems which carry the students through a process of:

- scenario description;

- background research;

- data analysis;

- policy analysis; and

- multi-stakeholder decision making.

The cost of development of such case problems can be quite high, often out of proportion with individual course budgets. Perdan et al. (2000) recognized the pivotal role of case problems in teaching sustainability and ethics in engineering. They developed interactive case-studies that could be used across the university (Perdan and Azapagic, 2003). However, the case studies were designed for chemical and process engineering and were not suitable for civil engineers. In our course, we used some off-the-shelf case-problems, drawn from an environmental engineering book (Wright, 2005) and developed others. The off-the-shelf case problems dealt with three issues in an fictional conurbation: satisfying energy needs, managing water in the city based on the patterns of demand and supply and protecting the city's fisheries from development. The case problems we developed included developing a transport strategy for a small Decision-making
paradigms 


\section{IJSHE \\ 9,2}

178
Scenario 1

You are a recent graduate. This is your first week, in your first job. You have been assigned to a team designing a shopping mall, for the third time in the last five years. You are asked to check the specifications for a set of concrete beams in mezzanine level of the mall, and recommend whether to keep them or change them, either because they are unsafe or too conservative

Scenario 2 You are a recent graduate. You have been working in the design office of your employer for six months. You have been performing brilliantly and are keen to get some construction site experience. One day, your boss calls you from the airport and says he needs you to go to site $\mathrm{D}$ for the next three months, and supervise and quality manage on-site concrete-making, including safety issues. He hangs up before you can ask what safety aspects you are responsible for. You go to the site the next day. As soon as you walk in, you are struck by the cavalier attitude to safety workers have. In fact, you can think of three health and safety rules that are being violated. Your boss cannot be reached. Obviously, few people on the site know you and you have little personal authority. You are not even certain of the level of official authority you carry. You are keen on having good personal relationships with the new team you are working with and do not want to lose face. Beside, who are you to change things around on the first day of work. On the other hand, this is quite serious and someone ought to do something about it. What do you do?

Scenario 3 You now have three years of work experience. You have been headhunted by another, fast-expanding firm. Your salary has skyrocketed. You have been appointed as site engineer for a bridge you have had a big part in designing. The project has been behind schedule and over budget and the client, a government authority, has been under immense political pressure to deliver. After joining, you find out that your predecessor was fired because he has been unable to keep to budget and was perceived as lacking problem-solving skills and being too fussy. You check the tender documents and you have a strong suspicion your company had underestimated the cost of the project in trying to win the bid. On site, you discover that the steel used in construction was lower quality than those specified in the bidding documents - same strength but higher maintenance. All steel material had already been bought by your company and delivered to the site. What do you do?

Scenario 4 Ten years into your career, you are senior manager at a plant manufacturing construction material. A fire at the onsite waste-water treatment plant has shut down the facility. You have a choice of either of either suspending manufacture for four weeks - the time it will take wastewater processing to restart - or to dump the waste in the adjacent river. You can keep dumping within legal limits. However, a new law, based on recent scientific findings about the susceptibility of local marine flora and fauna to pollution, bans dumping altogether and will come into effect six weeks later. In other words, dumping is legal but definitely harmful and wrong. If you suspend production, three major contracts will be at risk. What do you do?

Scenario $5 \quad$ You are the Head of Infrastructure Department in your local government. There has been a long-held vision of a bridge across a major bay. Significant economic benefits would arise from such a project. However, the bridge would lead to the demise of two fisheries and some recreational activities that have been a hallmark of this part of the city for a long time. Should you push for the building of the bridge or not? Should it be your own decision?

Scenario $6 \quad$ You are a City Planning Consultant with 20 year expertise in infrastructure projects. You have been asked by local government to provide advice on a transport development strategy for your town. The three major options are: (1) to invest in a major roadway expansion; (2) to upgrade the bus fleet and build a new major bus station; and (c) to build an subway train network. There are many winners and losers from the different options. How should you develop your recommendations?

Environmental and ethical decision-making scenarios within specific career paths, discussed with students
Note: In each scenario, students are asked to reflect on the type of skills required to make a sound decision 
town (an expanded version of scenario 6 in Table III), a study of a famous landslide disaster in Thredbo, Australia and a fictional case of whistle blowing in a public organization.

While the off-the-shelf cases are very well presented as an electronic package, simulate well engineering decision scenarios and cover a wide range of problems, policy questions are sometimes felt by students to be trivial. It has become clear to us that the importance of case problems goes beyond their roles in achieving specific learning outcomes and are crucial in engaging students in the learning process in the course. Such engagement, already made difficult by the perceived peripheral nature of the course, becomes weaker whenever the case problems fail to propel students along an investigative and reflective path, for the three-hour duration of the workshops. Therefore, an important future development, both for our course and the wider discipline of sustainability teaching to civil engineers, is a new design of some case problems, fictional and/or real, to make them more compelling to students and more effective in achieving learning outcomes.

\section{Teaching social sustainability}

The second difficulty we encountered pertains to the teaching of the social pole of the triple bottom line of sustainability. This dimension of the course encompasses the social impacts of engineering design, the politics of technological change and the role of engineers in decision-making processes. The teaching of social sustainability ought to lead to a deeper understanding of the social class bias of engineering experts, the role of the state in infrastructure development and its impacts on various communities and sub-groups, as well as the conflictual nature of environmental management. Given the strong social-science dimension of this aspect of the course and the techno-centric ideas prevalent among students, it is unsurprising that most are poorly equipped to engage with these issues at an undergraduate level. Calling into question the suitability of engineers and other technocrats as decision-makers, and offering alternative models of decision making has been particularly difficult. In addition, creating effective teaching simulacra of participatory decision-making processes such as community consultation, collective decision making and conflicts between stakeholders, requires significant resources and can be difficult to incorporate within the course structure. This has been recognized by other authors. A game approach advocated by Gondran et al. (2003) appears to be suitable for the multi-stakeholder nature of sustainability. However, while Lourdel et al. (2005) show that this approach has improved students understanding of sustainability, there is no evidence that the approach improves the skills of students at sustainable decision making. Ashford (2004) argues that the problem lies beyond individual courses and curricula and can be found in the wider structural constraints on traditional engineering schools which prevent the emergence of faculty members, curricula and syllabi that live up to the systemic change and inter-disciplinarity implicit in sustainability. However, he offers few answers as to how such a change can be effected. On a more practical note, a meeting of engineers and social scientists recommended a studio-type teaching environment as a way of foregrounding the social impacts of engineering design (Dym et al., 2003). In our course, each workshop runs for three hours and is largely independent of other workshops. This structure has proved to be unsuitable for exploring alternative decision-making scenarios which require longer time spans and carefully prepared role playing that may extend over a few weeks.

\section{Decision-making paradigms}


IJSHE 9,2

On the other hand, the number of students involved makes it difficult to run studio-like environments. These obstacles echo some of those raised by Boyle (2004) in an analysis of problems of teaching sustainability to engineers. A possible compromise, followed in our course, is to expose students to social sustainability perspectives through workshops and lectures, rather than attempt to bring about a significant change of attitude to techno-centrist decision making.

\section{Conclusion}

A decision-making paradigm provides a suitable framework for teaching sustainability and ethics. The success of this approach depends on the ability of teaching staff to engage students in reflections about their own professional perceptions and aspirations, as well as the skills they need in achieving them. This is particularly the case if technical and policy content, as well as theory and practice, are blended in the course. In fact, the ratio of theory to applications in course delivery ought to be carefully considered. A focus on theory would obviously be counter-productive, especially when aimed at a population of students in an applied science degree, accustomed to courses with very practical content. Conversely, a course entirely directed towards applications may fail to achieve its purpose, if it aims to change student thinking about engineering decision-making as a process that includes and goes beyond technical knowledge. Hence, the challenge to the engineering sustainability community in academia is to develop case problems whose content and progression can place sustainability in a wider ethics context, and mirror the conceptual ground covered in the lectures. Finally, incorporating social sustainability in such a course can only succeed if adequate teaching methods - that are resource, research and time intensive - are employed. These are necessary to foreground issues of stakeholder interests, political conflict and policy development processes that are at the heart of paradigms of socio-technological change.

\section{References}

Abdul-Wahab, S.A., Abdulraheem, M.Y. and Hutchinson, M. (2003), "The need for inclusion of environmental education in undergraduate engineering curricula", International Journal of Sustainability in Higher Education, Vol. 4, pp. 126-37.

Airey, D.W., Wilkinson, T. and Wood, G. (2005), "Revising the civil engineering curriculum at The University of Sydney", in Radcliffe, D. and Humphries, J. (Eds), Proceedings of the 4th ASEE/AaeE Global Colloquium on Engineering Education, Sydney, Australia, AaeE (CD-ROM).

Ashford, N.A. (2004), "Major challenges to engineering education for sustainable development: what has to change to make it creative, effective, and acceptable to the established disciplines?", International Journal of Sustainability in Higher Education, Vol. 5 No. 3, pp. 239-50.

Boyle, C. (2004), "Considerations on educating engineers in sustainability", International Journal of Sustainability in Higher Education, Vol. 5, pp. 147-55.

Bryce, P., Johnston, S. and Yasukawa, K. (2004), "Implementing a program in sustainability for engineers at University of Technology, Sydney: a story of intersecting agendas", International Journal of Sustainability in Higher Education, Vol. 5 No. 3, pp. 267-77.

Daly, H.E. (1992), "Allocation, distribution and scale: towards an economics which is efficient, just and sustainable”, Ecological Economics, Vol. 6 No. 3, pp. 185-93. 
Devon, R. (1999), "Towards a social ethics of engineering: the norms of engagement", Journal of Engineering Education, Vol. 88 No. 1, pp. 87-92.

Dick, K.J. and Stimpson, B. (1999), “A course in technology and society for engineering students”, Journal of Engineering Education, Vol. 88 No. 1, pp. 113-7.

Drake, M.J., Griffin, P.M., Kirkman, R. and Swann, J.L. (2005), "Engineering ethical curricula: assessment and comparison of two approaches", Journal of Engineering Education, Vol. 94 No. 2, pp. 223-31.

Dym, C.L., Wesnes, J.W. and Winner, L. (2003), "Social dimensions of engineering design: observations from Mudd Design Workshop III”, Journal of Engineering Education, Vol. 92 No. 1, pp. 105-7.

Fenner, R.A., Ainger, C.M., Cruickshank, H.J. and Guthrie, P.M. (2005), "Embedding sustainable development at Cambridge University Engineering Department”, International Journal of Sustainability in Higher Education, Vol. 6 No. 3, pp. 229-41.

Geli de Ciurana, A.M. (2006), "Education for sustainability in university studies experiences from a project involving European and Latin American universities", International Journal of sustainability in Higher Education, Vol. 7, pp. 81-93.

Gondran, N., Laforest, V. and Lourdel, N. (2003), "La complexite du jeu", Economie et Humanisme, Vol. 365, pp. 26-7.

Gorman, M., Hertz, M., Louis, G. and Mappili, L. et al., (2000), "Integrating ethics and engineering: a graduate option in systems engineering, ethics, and technology studies", Journal of Engineering Education, Vol. 89 No. 4, pp. 461-3.

GRI (2006), Global Reporting Initiative, available at: www.globalreporting.org

Haws, D.R. (2001), "Ethics instruction in engineering education: a (mini) meta-analysis", Journal of Engineering Education, Vol. 90 No. 2, pp. 223-30.

Heckert, J.R. (2000), "Engineering ethics education in the USA: content, pedagogy and curriculum”, European Journal of Engineering Education, Vol. 25 No. 4, p. 303.

Johnston, S.F., Gostelow, P. and King, J.P. (2000), Engineering and Society: Challenges of Professional Practice, Prentice-Hall, Englewood Cliffs, NJ.

Lourdel, N., Gondran, N., Laforest, V. and Brodhag, C. (2005), "Introduction of sustainable development in engineers' curricula. Problematic and evaluation methods", International Journal of Sustainability in Higher Education, Vol. 6 No. 3, pp. 254-64.

Nair, I. (1998), "Life cycle analysis and green design: a context for teaching design, environment, and ethics", Journal of Engineering Education, Vol. 87 No. 4, pp. 489-94.

Neumayer, E. (2004), Weak Versus Strong Sustainability: Exploring the Limits of Two Opposing Paradigms, 2nd ed., Edward Elgar Publishing, Aldershot, p. 296.

Paten, C.J.K., Palousis, N., Hargroves, K. and Smith, M. (2005), "Engineering sustainable solutions program: critical literacies for engineers portfolio", International Journal of Sustainability in Higher Education, Vol. 6, pp. 265-77.

Peet, D.J., Mulder, K.F. and Bijma, A. (2004), "Integrating SD into engineering courses at the Delft University of Technology: the individual interaction method", International Journal of Sustainability in Higher Education, Vol. 5 No. 3, pp. 278-88.

Perdan, S. and Azapagic, A. (2003), "Sustainable engineering design: an interactive multimedia case study", International Journal of Sustainability in Higher Education, Vol. 4 No. 1, pp. 33-43.

Perdan, S., Azapagic, A. and Clift, R. (2000), "Teaching sustainable development to engineering students", International Journal of Sustainability in Higher Education, Vol. 1 No. 3, pp. 267-79. 
IJSHE

9,2
Pérez-Foguet, A., Oliete-Josa, S. and Saz-Carranza, A. (2005), "Development education and engineering: a framework for incorporating reality of developing countries into engineering studies", International Journal of Sustainability in Higher Education, Vol. 6, pp. 278-303.

Self, D.J. and Ellison, E.M. (1998), "Teaching engineering ethics: assessment of its influence on moral reasoning skills", Journal of Engineering Education, Vol. 87 No. 1, pp. 29-34.

Turner, C.D., Li, W.W. and Martinez, A. (2001), "Developing sustainable engineering across a college of engineering", Proceedings of the 2001 American Society for Engineering Education Annual Conference \& Exposition, American Society for Engineering Education.

Vanderburg, W.H. (1999), "On the measurement and integration of sustainability in engineering education”, Journal of Engineering Education, Vol. 88 No. 2, pp. 231-5.

Wiedenhoeft, R.V. (1999), "Ecology and engineering: changing paradigms", Journal of Engineering Education, Vol. 88 No. 1, pp. 15-18.

Wilcox, J.R. (Ed.) (1998), Engineering and Environmental Ethics: A Case-Study Approach, Wiley, New York, NY, p. 303.

Wright, R.T. (2005), Environmental Science, Pearson Education International Prentice-Hall, Englewood Cliffs, NJ.

\section{About the authors}

Abbas El-Zein is a Senior Lecturer in environmental engineering at the School of Civil Engineering of the University of Sydney. His research interests include contaminant migration in the subsurface, computational modeling of environmental problems and the wider social and health context of environmental degradation. He has taught a range of environmental, computational and engineering subjects. Abbas El-Zein is the corresponding author and can be contacted at: aelzein@usyd.edu.au

David Airey is an Associate Professor in Geotechnical Engineering at the School of Civil Engineering of the University of Sydney, and Associate Dean for Learning and Teaching for the Faculty of Engineering and IT. His research interests include many aspects of experimental geomechanics and in particular laboratory testing of soil and rock. He currently teaches soil mechanics, instrumentation and communication subjects.

Peter Bowden is formerly Professor of administrative studies at the University of Manchester and currently honorary research associate at the Department of Philosophy of the University of Sydney. He lectures in ethics, with particular interests in engineering ethics, engineering codes of conduct and the organizational setting of engineering construction and design.

Henriikka Clarkeburn lectures in professional ethics in government and international relations, international business, and civil engineering. Her research interests include ethical decision-making in professional contexts, development of academic honesty and the pedagogy of ethics teaching in tertiary education. She has published in various international journals on ethics teaching, academic honesty and health care ethics.

To purchase reprints of this article please e-mail: reprints@emeraldinsight.com Or visit our web site for further details: www.emeraldinsight.com/reprints 
Reproduced with permission of the copyright owner. Further reproduction prohibited without permission. 